Goldschmidt 2021 Abstract

https://doi.org/10.7185/gold2021.7518 cycling could prove useful in refining regional and global estimates of volatile recycling efficiency.

\title{
Stable isotope, noble gas, and forward modelling insights into the fate of volatiles subducted along the Hikurangi Margin, New Zealand
}

\author{
GABE S EPSTEIN ${ }^{1}$, GRAY E. BEBOUT ${ }^{1}$, BRUCE \\ CHRISTENSON $^{2}$, HIROCHIKA SUMINO ${ }^{3}$, IKUKO WADA ${ }^{4}$, \\ CYNTHIA A WERNER ${ }^{5}$ AND DAVID R HILTON ${ }^{6}$ \\ ${ }^{1}$ Lehigh University \\ ${ }^{2}$ GNS-Lower Hutt \\ ${ }^{3}$ The University of Tokyo \\ ${ }^{4}$ University of Minnesota \\ ${ }^{5}$ Research Geologist (contractor) \\ ${ }^{6}$ Scripps Oceanographic Institute, University of California, San \\ Diego \\ Presenting Author: gse216@lehigh.edu
}

We present a multidisciplinary assessment of volatile production associated with subduction of the Hikurangi Plateau beneath the North Island of New Zealand. We quantitatively assess the input and output of $\mathrm{CO}_{2}$ and $\mathrm{N}_{2}$ based on the chemical and stable isotope composition of seafloor sediments and basaltic breccias (from IODP 375), previously accreted metasedimentary rocks (Torlesse and Waipapa Terranes), and volcanic/hydrothermal gases sampled from North Island fumaroles and springs (together with noble gas data for the latter). These results are compared with a 3-D thermo-petrologic models for four lithologic structures: a typical section of oceanic crust and serpentinized mantle peridotite as well as three idealized plateau structures containing variably altered, thickened oceanic crust. Devolatilization reactions and volatile loss are calculated using the thermodynamic software Perple_X assuming instantaneous fluid loss (i.e. approximating channelized fluid flow).

The model results indicate that $30-85 \%$ of initially subducted $\mathrm{C}$ and $5-12 \%$ of $\mathrm{N}$ is lost from the slab during metamorphism at forearc to subarc depths, with both volatiles being dominantly sourced from altered oceanic crust with some contribution from subducted sediment at the forearc-arc transition $(75-90 \mathrm{~km}$ depth). Gabbro and serpentinized peridotite do not supply appreciable $\mathrm{CO}_{2}$ or $\mathrm{N}_{2}$.

The $\delta^{13} \mathrm{C}_{\mathrm{VPDB}}$ and $\mathrm{CO}_{2}{ }^{\beta} \mathrm{He}$ values for the arc gases range from -8.3 to $-1.4 \%$ and $2 \times 10^{9}$ to $2.7 \times 10^{11}$, indicating contributions from slab carbonate, organic $\mathrm{C}$ (subducted and/or assimilated), and mantle $\mathrm{C}$ of $67 \%, 30 \%$, and $3 \%$, respectively. The concentration of organic $\mathrm{C}$ in the subducted sediment is insufficient to account for the $\delta^{13} \mathrm{C}$ signature of gases, requiring addition by tectonic erosion and/or crustal assimilation. The $\delta^{15} \mathrm{~N}_{\text {air }}$ and $\mathrm{N}_{2} /{ }^{36} \mathrm{Ar}$ values of arc gases are -1.0 to $+2.3 \%$ and $1.54 \times 10^{4}$ to $1.9 \times 10^{5}$, indicating slab and mantle contributions of $70 \%$ and $30 \%$. These calculations yield whole-margin fluxes of 5.4-7.0 Tg/yr for $\mathrm{CO}_{2}$ and $0.0023-0.0061 \mathrm{Tg} / \mathrm{yr}$ for $\mathrm{N}_{2}$, corresponding to $\sim 2.2 \%$ and $1-30 \%$ of the global $\mathrm{CO}_{2}$ and $\mathrm{N}_{2}$ flux from subaerial volcanoes worldwide (with global $\mathrm{N}_{2}$ flux being poorly constrained). This unique assessment of volatile 